\title{
WACin journal
}

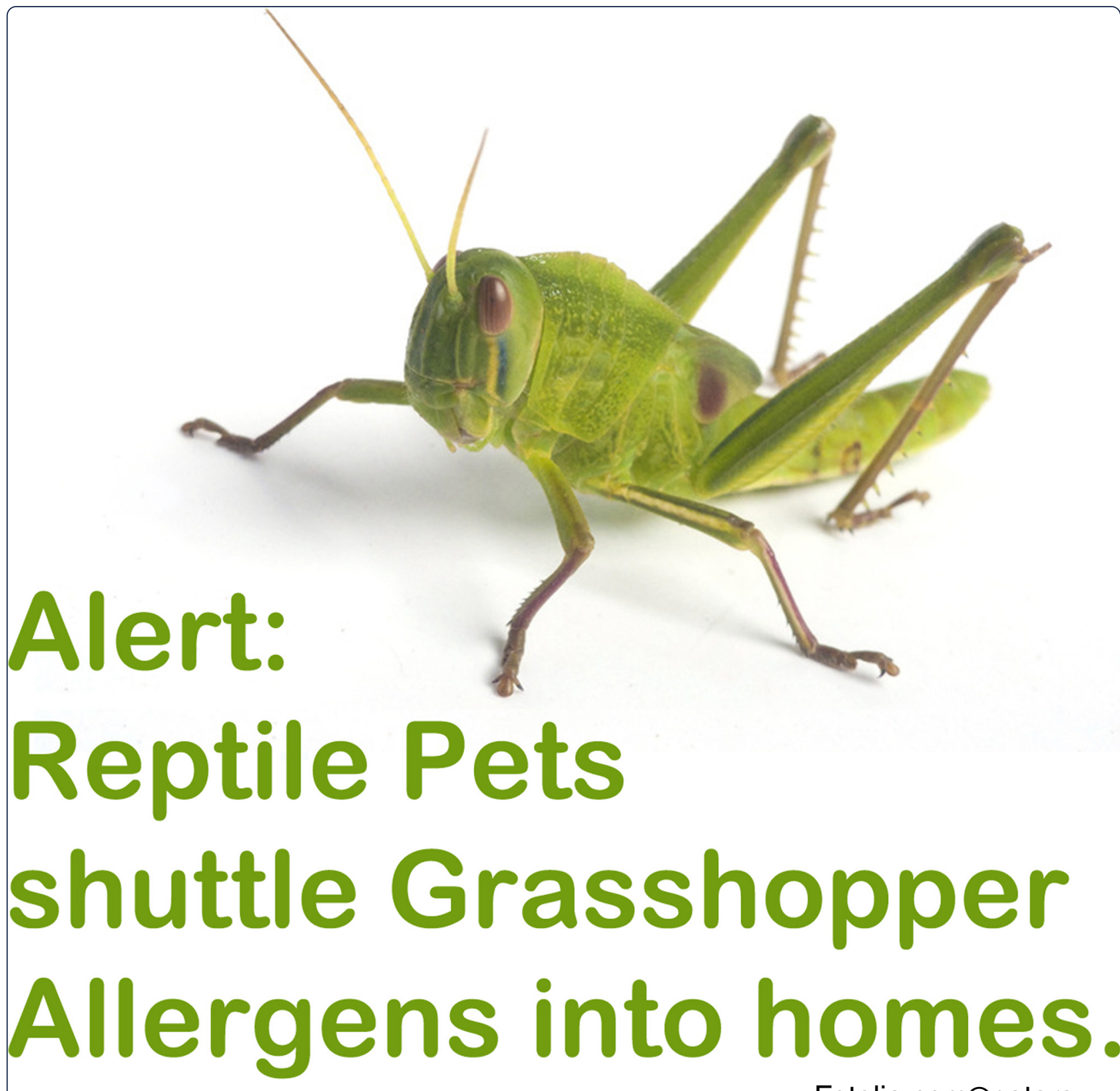

Fotolia.com@natara

\section{Caution: Reptile pets shuttle grasshopper allergy and asthma into homes}

Jensen-Jarolim et al. 


\title{
Caution: Reptile pets shuttle grasshopper allergy and asthma into homes
}

\author{
Erika Jensen-Jarolim ${ }^{1,2^{*}}$, Isabella Pali-Schöll ${ }^{1,2}$, Sebastian A.F. Jensen ${ }^{3}$, Bruno Robibaro ${ }^{3,4}$ and Tamar Kinaciyan ${ }^{5}$
}

\begin{abstract}
The numbers of reptiles in homes has at least doubled in the last decade in Europe and the USA. Reptile purchases are increasingly triggered by the attempt to avoid potentially allergenic fur pets like dogs and cats. Consequently, reptiles are today regarded as surrogate pets initiating a closer relationship with the owner than ever previously observed. Reptile pets are mostly fed with insects, especially grasshoppers and/or locusts, which are sources for aggressive airborne allergens, best known from occupational insect breeder allergies. Exposure in homes thus introduces a new form of domestic allergy to grasshoppers and related insects. Accordingly, an 8-year old boy developed severe bronchial hypersensitivity and asthma within 4 months after purchase of a bearded dragon. The reptile was held in the living room and regularly fed with living grasshoppers. In the absence of a serological allergy diagnosis test, an IgE immunoblot on grasshopper extract and prick-to-prick test confirmed specific sensitization to grasshoppers. After 4 years of allergen avoidance, a single respiratory exposure was sufficient to trigger a severe asthma attack again in the patient.

Based on literature review and the clinical example we conclude that reptile keeping is associated with introducing potent insect allergens into home environments. Patient interviews during diagnostic procedure should therefore by default include the question about reptile pets in homes.
\end{abstract}

Keywords: Grasshopper, Reptile, Asthma, Pets, Reptile pets, IgE, Allergy

\section{Review}

\section{Reptile pets and their allergenic food}

Insects as alien species may represent transient threats, or get invasive and established [1]. Trade and transport play an important role in their dispersal as contamination or as goods $[2,3]$. Insects represent a growing market segment, not only because edible insects likely in the future will be increasingly popular for our own food, but also because insects have since long been used in industrial feeds for domestic animals such as poultry [4], or for reptiles in research labs and homes. In this context, the production of a single cricket farm raised from 10 million animals a week in 2004 up to 25 million in 2012, according to a report by the European Association of Reptile Keepers

\footnotetext{
* Correspondence: erika.jensen-jarolim@meduniwien.ac.at

${ }^{1}$ Comparative Medicine, Messerli Research Institute, University of Veterinary Medicine Vienna, Medical University Vienna and University Vienna, Vienna, Austria

${ }^{2}$ Institute of Pathophysiology and Allergy Research, Center of Pathophysiology, Infectiology and Immunology, Medical University Vienna, Waehringer G. 18-20, 1090 Vienna, Austria

Full list of author information is available at the end of the article
}

(EURAK) [5]. Pet stores and pet superstores distribute these insects, all while alive. Thus in parallel with the strong trend towards home reptiles in the US and Europe [6], these "alien" insect species have been introduced on purpose in our ultimate living environment as feed for reptiles. It may be doubted that through this rapid change any reasonable co-evolutionary interaction outcome may take place [7], but rather unwanted side effects could occur.

The number of insects actually living in our homes is not known, and can only be estimated indirectly by correlation to the number of domestic reptiles. The report of the White House quotes the American Pet Products Association, according to which "pet reptile" owning US households increased by $68 \%$, from 2.8 million households in 1994 to 4.7 million in 2008 [6]. According to EURAK, 8 million reptile pets are kept in UK in 1.1 million households [5]. Reptiles have also become popular in Europe. In a statement on Salmonella infections via exotic reptiles, the Robert Koch-Institute quotes the German Industry association of Pet market, saying that purchases of 
terraria have increased by $6.1 \%$ in 2008 , that $1.2 \%$ of German households own reptiles, and that especially keeping of dragon species (genus Pogona, family Agamidae), or Iguanidae has increased tenfold [8].

Considering that on average 4 living grasshoppers with each a weight of $0.5 \mathrm{~g}$ are fed to a medium size dragon per week, $1.120 \mathrm{~kg}$ grasshoppers are eaten by a single reptile during its life time of optimally 10 years.

Reptile holders were classified as i) beginners who intend to buy an easy-to-handle and non-expensive animal, ii) enthusiasts with deep interest and knowledge in reptiles, and iii) hobbyists who also engage in breeding [6]. We may here add another category, namely iv) families with pet allergies or increasing awareness of allergies to furry animals [9]. The acquisition of a reptile may then be associated with a change of the attitude towards reptiles from biological interest to strong emotional binding to the surrogate pet $[10,6]$. The close contact between child, owner and reptile results in contamination of textiles and furniture with leftovers of the insect feed from skin and feces of the reptile. This is not only a problem in terms of Salmonella infection [8], but grasshoppers have since long also been known to pose an allergenic risk: The first observation of grasshopper allergy was reported in 1953 [11], shortly after followed by the understanding that these insects may cause allergic asthma in occupational settings [12]. For instance locusts, grasshoppers and cricketts are bred for research laboratories [13, 14] or for reptile feed market $[6,5]$. It was perceived that especially a high respiratory exposure with dust of insects including grasshoppers is associated with a risk for allergic rhinoconjunctivitis and bronchial hyperreactivity and asthma $[15,16]$. In this study, sensitization was seen in $43.8 \%$ of occupationally exposed workers as compared to $3.8 \%$ of control subjects. Further the skin test correlated better with asthma symptoms than cutaneous symptoms in 4 workers with asthma. Whereas contact allergy is mainly due to an underlying type IV reactivity and may result from occupational exposure [17], the present review focuses on immediate type (type I) allergies.

Of 15 occupationally exposed grasshopper workers, contacts with the allergen provoked acute respiratory and cutaneous symptoms in five of them [18]. The IgEbinding allergens were described in terms of molecular mass, but not further identified. Interestingly, the authors demonstrated that air-sampler filters in the grasshopper breeding room could capture allergen, and that it corresponds to antigens derived from locust gut.

The question whether natural migration of locust swarms may produce allergen levels that even result in asthma [19] is hotly debated. In their own study, 6 of 10 laboratory workers exposed to African grasshopper Locusta migratoria showed symptoms ranging from urticaria to rhinoconjunctivitis. It could be demonstrated that locust allergens (and particularly a newly described $70 \mathrm{kDa}$ allergen) were especially contained in the wings of the animals, but also in the feces.

In a British study, 32 workers of a food supplier, breeding insects for exotic pets, were investigated [20], with $34 \%$ reporting work-related symptoms. The dust levels reached $1.2-17.9 \mathrm{mg} / \mathrm{m}^{3}$ with concomitantly high endotoxin levels of up to $29.43 \mathrm{kEU} / \mathrm{m}^{3}$ [21], compared to the endotoxin concentration of $18.0 \mathrm{kEU} / \mathrm{m}^{3}$ in an average classroom [22]. This is interesting as principally, via tolllike receptor 4 (TLR4) the release of TSLP (thymic stromal lymphopoietin) from bronchial epithelia could be triggered supporting Th2 skewing [23]. Similarly, grasshopper allergens especially in context with endotoxin could lead to respiratory hypersensitivity.

Grasshopper allergy has been discussed also in the pediatric population [24, 25]. When asthmatic US children were screened by RAST discs coupled with insect extracts for specific IgE, 7 of 36 (19\%) asthmatics reacted to grasshopper extracts, however, without approval of a clinical relevance [26]. In 2009 Prasad et al. skin-pricked 2880 Indian patients with allergic rhinoconjunctivitis and revealed that insects were the most important cause of sensitization in $21.1 \%$ of tested patients, with $20.8 \%$ of them being specifically sensitized against grasshoppers [27].

When sera from patients with a history of respiratory allergies to insects of several kinds (house fly, blowfly, clothes moth, warehouse moth, cockroach, carpet beetle, silverfish) were tested for IgE binding, $30 \%$ reacted with all seven species, and $50 \%$ reacted with four extracts. Comparison with additional 11 species including Australian plague locust (Chortoicetes terminifera) revealed that common crossreactive allergens are present in different species possibly responsible for a "pan allergy" to insects [28]. This concept was supported by the identification of the pan allergen tropomyosin in the study of Leung, when nine shrimp allergic sera reacted also to insects including long-horned grasshopper (Tettigoniidae), cockroach and fruit fly [29]. Pener et al. in their comprehensive review on allergy to locusts and acridid grasshoppers expressed the urgent need that "the molecular structure of the allergens" should be revealed [30].

\section{Clinical example: Specific sensitization to grasshopper in a reptile home}

A bearded dragon was purchased by the parents of an eight-year old boy (family A) as pet surrogate and installed with its terrarium in the living room of an apartment in Vienna. Four months later, the boy experienced several episodes during the nights awaking with glottal edema and wheezing, prompting the parents to refer to a children's hospital in Vienna, Austria, where the situation could be controlled with beta-2-mimetic aerosol and rectal hydrocortisone. The 
provisory diagnosis was "pseudo croup presumably elicited by viral infections". We carefully elaborated the case investigating all possible respiratory allergen sources including pets. The only pet was bearded dragon "Sony", being fed with 3-4 living grasshoppers a week. We performed a Prick test with standard inhalant allergen series and Prick-to-Prick test using the wing of one Egyptian grasshopper, the species being fed the reptile by the boy, and the saliva of the bearded dragon. Only Prick-to-Prick test with the wing of the grasshopper elicited a pronounced wheal and flare reaction (Fig. 1a), all other skin tests resulted negative. The boy was atopic (total IgE level: $168 \mathrm{kU} / \mathrm{l}) ;$ CAP RAST FEIA: rye and grass pollen class II, birch and mugwort pollen class I without any clinical relevance; on an ISAC ImmunoCAP microarray minimal sensitization to grass and cypress pollen again without clinical relevance could be detected, but no IgE-reactivity to any of the insect or mollusk tropomyosins. As no commercial IgE diagnostics for grasshopper allergy was available we extracted proteins in PBS containing protease inhibitors EDTA and EACA from either wings or legs from Egyptian grasshoppers (Anacridium aegyptium, $A A$ ) or from migratory locust (Locusta migratoria, $L M$ ). Extracts were lyophilized and freeze dried until use,

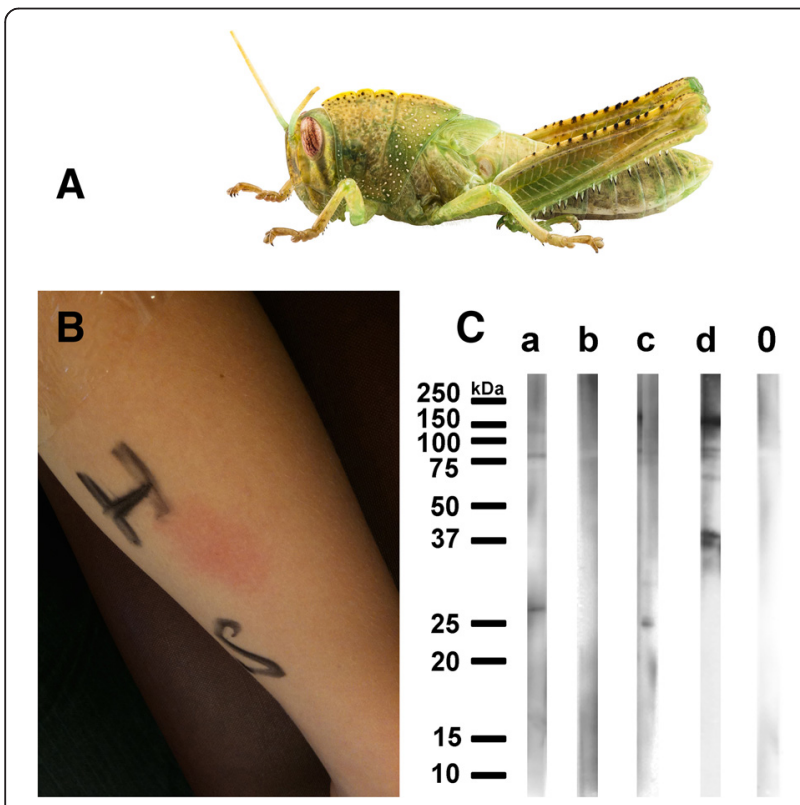

Fig. 1 a Nymph of Egyptian locust species Anacridium aegyptium (Fotolia@ paulrommer). b Confirmation of specific sensitization by Prick-to-Prick test with Egyptian grasshopper.Crushed wing material of a frozen Egyptian locust $(\mathrm{H})$ and saliva of the boy's bearded dragon Sony (S) was pricked on the forearm of the patient, in addition to the standard Prick test with inhalant allergens. c Reactivity of patient's lgE on blotted extracts of migratory grasshopper (Locusta migratoria) legs (a) and wings (b), and from Egyptian locust (Anacridium aegypticum) legs (c) and wings (d). As negative control, a serum of a non-allergic person was tested (0). Bound lgE was detected by peroxidase-labeled anti-lgE antibody and the reaction developed with $\mathrm{ECL}$ separated at 50 microg/lane on a $15 \%$ reducing SDSPAGE and blotted to nitrocellulose. Fig. 1b shows that patient's IgE was directed against 27, 80 and $125 \mathrm{kDa}$ proteins of LM leg extract (lane A), and to proteins > $250 \mathrm{kDa}$ in LM wing extract (B); in AA leg extract IgE detected bands at 25,75 and $90 \mathrm{kDa}(\mathrm{C})$, and in AA wing extract at a molecular weight of $36,38,70,76,90$, and $152 \mathrm{kDa}(\mathrm{D})$. We did not detect IgE binding to recombinant shrimp tropomyosin or troponin in the immunoblot (data not shown).

The patient's parents were encouraged to get rid of the animal due to the severity of the allergic reaction in the absence of any causal treatment. The bearded dragon was therefore transferred to family B in the same house, and the allergic boy did never since enter their apartment. However, 4 years after the first event, the boy (now aged 12) stopped by at the door of family B, who still owned the bearded dragon plus several snakes and other reptiles. Inhalation of warm air streaming out of this apartment to the colder corridor resulted in shortened breath due to acute bronchial obstruction: approx. $4 \mathrm{~h}$ later the patient awoke with wheezing being recognized and treated by the parents with $100 \mathrm{mg}$ intra-rectal hydrocortisone. The following day, when the boy's respiratory condition was stable and the lung function almost recovered, the persisting grasshopper sensitization was confirmed in a skin prick test.

The patient was released with a prophylactic prescription of beta-2-mimetics aerosol, oral anti-histamines, rectal hydrocortisone and an epinephrin autoinjector.

\section{Conclusion}

There is strong evidence that grasshoppers have a high allergenic potential and increasingly are invading our homes together with the reptile pets. So far, besides occupational grasshopper allergies no private sensitizations were described, but have to be expected considering the great market growth of reptiles and associated insects for feed. We evidence here that indeed via grasshoppers as feed for reptiles within a short time period a highly specific, clinically relevant hypersensitivity with severe asthma can be induced with a long-term memory. The reptile keeping in the home results in airborne dissemination of allergens from wings, legs and -according to the literature [30] - from the peritrophic envelope of feces, and at an allergen level sufficient for sensitization as well as triggering of symptoms.

\section{Consent}

Written informed consent was obtained from the patient and his parents for this publication and accompanying images. A copy of the written consent is available for review by the Editor-in-Chief of this journal. 


\section{Abbreviations}

AA: Anacridium aegyptium; EACA: Epsilon-aminocaproic acid (EACA); ECL: Enhanced chemiluminescence; EDTA: Ethylenediamine tetraacetic acid; EURAK: European Association of Reptile Keepers; LM: Locusta migratoria; PBS: phosphate buffered saline; RAST: Radioallergosorbent test; SDS PAGE: Sodium dodecyl sulfate-polyacrylamide electrophoresis; TLR: Toll-like receptor; TSLP: Thymic stromal lymphopoietin; US: United States.

\section{Competing interests}

The authors declare that they have no competing interests.

\section{Authors' contributions}

EJJ Designed the study, elaborated the case, directed clinical and laboratory tests, performed literature review and wrote the manuscript. IP Helped in elaborating the case, supervised extraction of grasshoppers and lgE immunoblot analysis, arranged the figure and proofread the manuscript. SAFJ did grasshopper extraction, skin tests and proofreading manuscript. BR investigated the lung function of the patient and proofread the manuscript. TK Elaborated the case, performed the skin tests during the first consultation of the patient, made the diagnosis, and proofread the manuscript.

\section{Acknowledgements}

The study was supported by the Austrian Science Fund (FWF) project F4606-B19. We would like to thank the patient and his parents for collaboration during the production of this manuscript. Further, thanks to Bellinda Neuherz, AllergyCare, Vienna, for excellent help in the patient work-up.

\section{Author details}

${ }^{1}$ Comparative Medicine, Messerli Research Institute, University of Veterinary Medicine Vienna, Medical University Vienna and University Vienna, Vienna, Austria. ${ }^{2}$ Institute of Pathophysiology and Allergy Research, Center of Pathophysiology, Infectiology and Immunology, Medical University Vienna, Waehringer G. 18-20, 1090 Vienna, Austria. ${ }^{3}$ AllergyCare, Allergy Diagnosis and Study Center, 1220 Vienna, Austria. ${ }^{4}$ The Rudolfinerhaus, Vienna, Austria ${ }^{5}$ Division of Immunology, Allergy and Infectious Diseases, Department of Dermatology, Medical University Vienna, Vienna, Austria.

\section{Received: 26 March 2015 Accepted: 29 May 2015}

\section{Published online: 17 August 2015}

\section{References}

1. Shirley SM, Kark S. Amassing efforts against alien invasive species in Europe. PLoS Biol. 2006;4(8), e279. doi:10.1371/journal.pbio.0040279.

2. Bacon SJ, Bacher S, Aebi A. Gaps in border controls are related to quarantine alien insect invasions in Europe. PLOS ONE. 2012;7(10), e47689. doi:10.1371/journal.pone.0047689.

3. Banks NC, Paini DR, Bayliss KL, Hodda M. The role of global trade and transport network topology in the human-mediated dispersal of alien species. Ecol Lett. 2015;18(2):188-99. doi:10.1111/ele.12397.

4. Van Huis A, Van Itterbeeck J, Klunder H, Mertens E, Halloran A, Muir G et al. Edible insects. Future prospects for food and feed security. In: http:// www.fao.org/docrep/018/i3253e/i3253e.pdf. Rome. 2013.

5. Publication of European Union Association of Reptile Keepers (EUARK). In: http://www.fbh.org.uk/news/downloads/euark_brochure_2012.pdf. UK. 2012.

6. Collis A, Fenili M. The Modern U.S. Reptile Industry Publications of the White House, President Barack Obama. In: http://www.whitehouse.gov/sites/ default/files/omb/assets/oira_1018/1018_04182011-3.pdf. Georgetown Economic Services, LLC Economic Analysis Group, Jan 5th, 2011

7. Saul WC, Jeschke JM. Eco-evolutionary experience in novel species interactions. Ecol Lett. 2015;18(3):236-45. doi:10.1111/ele.12408.

8. The Robert Koch-Institute. Salmonella-Infektionen bei Säuglingen und Kleinkindern durch Kontakt zu exotischen Reptilien. Epidemiologisches Bulletin. 2013;9:71-82

9. San Miguel-Moncin MM, Pineda F, Rio C, Alonso R, Tella R, Cistero-Bahima A. Exotic pets are new allergenic sources: allergy to iguana. Curr Opin Allergy Clin Immunol. 2006;16(3):212-3.

10. Blahak S. Tierärztliche Arbeitsgemeinschaft Amphibien und Reptilienkrankheiten, Deutsche Gesellschaft für Herpetologie und Terrarienkunde, Arbeitsgruppe Reptilien und Amphibien in Privathand. Stellungnahme zur Haltung von Reptilien und Amphibien in Privathand in Deutschland. Deutsches Tierärzteblatt. 2009;11:1468-76.

11. Frankland AW. Locust sensitivity. Annals of Allergy. 1953;11(4):445-53.
12. Von der Bijl WJ. Asthma als Berufskrankheit: Allergie gegen Heuschrecken. Allergie und Asthma (Asthma as an occupational disease: Allergy to grasshoppers). Allerg Asthma 1963; Jul (9):154-5.

13. Burge PS, Edge G, O'Brien IM, Harries MG, Hawkins R, Pepys J. Occupational asthma in a research centre breeding locusts. Clinical Allergy. 1980;10(4):355-63.

14. Soparkar GR, Patel PC, Cockcroft DW. Inhalant atopic sensitivity to grasshoppers in research laboratories. Curr Opin Allergy Clin Immunol. 1993;92(1 Pt 1):61-5.

15. Fuchs E. Insects as inhalant allergens. Allergol Immunopathol. 1979;7(3):227-30.

16. Wirtz RA. Allergic and toxic reactions to non-stinging arthropods. Annu Rev Entomol. 1984;29:47-69.

17. Monk BE. Contact urticaria to locusts. The British Journal of Dermatology. 1988;118(5):707-8.

18. Tee RD, Gordon DJ, Hawkins ER, Nunn AJ, Lacey J, Venables KM, et al. Occupational allergy to locusts: an investigation of the sources of the allergen. Curr Opin Allergy Clin Immunol. 1988;81(3):517-25.

19. Lopata AL, Fenemore B, Jeebhay MF, Gade G, Potter PC. Occupational allergy in laboratory workers caused by the African migratory grasshopper Locusta migratoria. Allergy. 2005;60(2):200-5. doi:10.1111/j.1398-9995.2005.00661.x.

20. Harris-Roberts J, Fishwick D, Tate P, Rawbone R, Stagg S, Barber CM, et al. Respiratory symptoms in insect breeders. Occup Med. 2011;61(5):370-3. doi:10.1093/occmed/kqr083.

21. Semple S, Devakumar D, Fullerton DG, Thorne PS, Metwali N, Costello A, et al. Airborne endotoxin concentrations in homes burning biomass fuel. Environ Health Perspect. 2010;118(7):988-91. doi:10.1289/ehp.0901605.

22. Jacobs JH, Krop EJ, Borras-Santos A, Zock JP, Taubel M, Hyvarinnen A, et al. Endotoxin levels in settled airborne dust in European schools: the HITEA school study. Indoor Air. 2014;24(2):148-57. doi:10.1111/ina.12064.

23. Hammad H, Chieppa M, Perros F, Willart MA, Germain RN, Lambrecht BN. House dust mite allergen induces asthma via toll-like receptor 4 triggering of airway structural cells. Nat Med. 2009;15(4):410-6. doi:10.1038\%2Fnm.1946.

24. Bergner RK. Letter: Misconceptions regarding grasshopper allergy. Pediatrics. 1974;54(2):255-6.

25. Schnitzker WF. Grasshopper allergy. Pediatrics. 1974;53(2):280-1.

26. Lierl MB, Riordan MM, Fischer TJ. Prevalence of insect allergen-specific IgE in allergic asthmatic children in Cincinnati. Ohio Annals of Allergy. 1994;72(1):45-50.

27. Prasad R, Verma SK, Dua R, Kant S, Kushwaha RA, Agarwal SP. A study of skin sensitivity to various allergens by skin prick test in patients of nasobronchial allergy. Lung India : official organ of Indian Chest Society. 2009:26(3):70-3. doi:10.4103/0970-2113.53228.

28. Baldo BA, Panzani RC. Detection of IgE antibodies to a wide range of insect species in subjects with suspected inhalant allergies to insects. International Archives of Allergy and Applied Immunology. 1988;85(3):278-87.

29. Leung PSC, Chow WK, Duffey S, Kwan HS, Gershwin ME, Chu KH. IgE reactivity against a cross-reactive allergen in crustacea and mollusca: evidence for tropomyosin as the common allergen. Curr Opin Allergy Clin Immunol. 1996;98(5 Pt 1):954-61.

30. Pener MP. Allergy to Locusts and Acridid Grasshoppers: a Review. Journal of Orthoptera Research. 2014;23(1):59-67.

\section{Submit your next manuscript to BioMed Central and take full advantage of:}

- Convenient online submission

- Thorough peer review

- No space constraints or color figure charges

- Immediate publication on acceptance

- Inclusion in PubMed, CAS, Scopus and Google Scholar

- Research which is freely available for redistribution 